\title{
An Analysis on the Musical Approaches Between the Violoncello and Other Works of Turkish Five Composers in Terms of Composition Period
}

\author{
Aslı Beller \\ State Conservatory, Anadolu University, PO Box 26050, Eskişehir, Turkey \\ aslibeller@anadolu.edu.tr
}

\begin{abstract}
One of the breakthroughs that occurred along with the establishment of the Turkish Republic was in the field of art. Mustafa Kemal Atatürk, who attached great importance to art, supported every kind of development in this field and became a pioneer even in hard conditions. Composers, who lived in the first years of the Turkish Republic and are called Turkish Five today, made great effort for the development of art in our country. These composers had studied abroad through the scholarships provided by Ministry of National Education and made breakthroughs when they came back to our country after having made great progress in their fields. Cemal Reşit Rey, Hasan Ferid Alnar, Ulvi Cemal Erkin, Ahmed Adnan Saygun and Necil Kazım Akses are regarded as Turkish Five. Each of them brought in important works in the field of art and contributed a lot to the introduction of Turkish music to the world. In this study, Turkish Five were analyzed in terms of their composition period. Analysis of the common points of violoncello works of the composers as well as other works they composed in the same period and their musical approaches was aimed. In which year and by which composer the works were composed are going to be analyzed and periodic similarities and differences are going to be presented. There are violoncello works of the composers in literature except Ulvi Cemal Erkin.
\end{abstract}

Keywords: Violoncello, Rey, Alnar, Erkin, Saygun, Akses, Turkish Five

DOI: $10.7176 / \mathrm{ADS} / 96-02$

Publication date: November $30^{\text {th }} 2021$

\section{Introduction}

With the proclamation of the Republic on 29 October 1923, Turkey took the first steps towards renewal through a brand new system of government. Revolutionary reforms started with the republic and new face of Turkey was presented to the whole world. The most important field in this introduction process was in fine arts. Performing arts and music had a significant place in the developing face of Turkey. Turkish musicians were introduced to the conservatory education. Within this context, influential developments related to composers and singers started to be experienced. First generation composers our country, who created works in Classical Western Music are referred as Turkish Five today. These composers are

-Cemal Reşit Rey (1904-1985)

-Hasan Ferit Alnar (1906-1978)

-Ulvi Cemal Erkin (1906-1972)

-Ahmed Adnan Saygun (1907-1991)

-Necil Kazım Akses (1908-1999), respectively.

It can be said that the name Turkish Five was given based upon "Russian Five" and "French Six". It is not possible to say that there was a close cooperation that the Russian and the French had among Turkish Five. What Turkish Five had in common was that all five of them tended towards Turkish music sources. Each of them grew up in different families, and started musical education in different ways. Cemal Reşit Rey, Ulvi Cemal Erkin and Ahmed Adnan Saygun went to France, Hasan Ferit Alnar and Necil Kazım Akses went to Vienna with state scholarship and completed their education in these countries. Turkish five took our music a step forward by synthesizing Turkish music and western music. Musiki Muallim Mektebi (Music Teacher's School) which was the first music teacher's school and taught our first generation composers and singers was opened with Tevhid-i Tedrisat (educational law) in 1924. Palace Orchestra which was settled in İstanbul was transferred to capital Ankara and was named as (Riyaset-i Cumhur Musiki Heyeti) Presidential Symphony Orchestra. After all these developments, (Darülelhan) Istanbul State Conservatory which was established in İstanbul, in Constitutional Monarchy Period in 1926 was transformed to city conservatory. Fixation and Sorting Council started to operate in the same year. This council notated and archived folk songs. Presidential Symphony Orchestra presented cultural structure of Turkey to Europe through the concerts they performed in a four month tour program (ekitap.ktb.gov.tr). These new musical schools started to yield in a year, young musicians who had been taught various educational institutions, started to be appointed to Music Teacher's School. Singing Societies that sang different anthems and polyphonic songs were constituted in 1927, compositions composed with contemporary techniques started to appear in 1930. Community centers that were established in 1932 played a crucial role in 
the recognition and spread of Turkish music. Turkish Five were among all these innovations. Composers that have different duties and status aimed to bring the music of our country to a higher level by continuing their works.

\section{Cemal Reșit Rey (1904-1985)}

Cemal Reşit Rey who was born in Jerusalem in 1904 was the oldest member of Turkish Five. He started music with the piano lesson he learned from his mother and composed his first work when he was 8 . When his parents returned to İstanbul, he continued his education Galatasaray High School, and then the family had to leave the country and moved to Paris. Cemal Reşit Rey continued his education at Lycee Buffon. At the same time, he started to take lessons from famous piano pedagogue Marguerite Long. Rey who continues his education in France and his family had to move to Geneva with the outbreak of World War I. Here, he attended St. Antoine Collage and Geneva Conservatory. Rey who came back to Paris in 1920, studied composition with Raoul Laparra, musical aesthetics with Gabriel Faure and conductorship with Henri Defosse. He signed his name a lot of piano recitals and composition in Paris where he stayed for 3 years. He returned to Turkey with the proclamation of the republic in 1923, and started to teach in piano and composition classes in Darülelhan (later İstanbul State Conservatory). He had founded a choir in 1926 and a string band in 1934, later when the wind instruments attended; the group became a symphonic orchestra. The group was named as İstanbul State Orchestra in 1945 and it was called as İstanbul State Symphony Orchestra in 1972 (ataturkansiklopedisi.gov.tr.). It is possible to divide the works of Cemal Reşit Rey into periods, as it is of all composers. Since he was living in France, he got inspired from French songs and operas from 1919 to 1926 that coincides with the first year of his compositions. He frequently utilized the tunes of Turkish Folk Music in his works between 1926 and 1931 when he came back to Turkey and he produced works with the contemporary composition techniques for the development of Turkish music. He was influenced by operettas and revues between 1930 and 1950 and he performed collective works with his brother. Sufism and Turkish music were in the forefront in his works that he produced after 1950 and he composed extensive orchestral works. A lot of works such as piano, orchestra, singing, choir, theatric music are in the repertoire of Rey. The artist, who received a lot of prizes throughout his artistic life, was awarded as a state artist in 1982. Until his death in 1985, he continued to work in İstanbul Mimar Sinan University State conservatory. Cemal Reşit Rey composed two works for violoncello. These are;

- " "Introduction and Dance" Concertant for Violoncello and Orchestra (1928)

"Concertant Pieces" (1952-1954)

The first one of these works is his work called "Introduction and Dance" concertant for violoncello and orchestra which he composed in 1928. Since the notes of this work can not be accessed, it only appears in the literature and any reviews could not be performed about this work. This work is from the second period of Rey's works. He attached importance to the development of the Turkish music in this period and produced compositions in line with this approach. La Legende du Bebek (1928), Scéne Turques four pieces (about Turkish Folk Dance), 1928, Chants d'Anatolie (four songs), 1926, Scénes Turques six pieces about Anatolian Songs (Heugel Press, Paris), 1928 can be the examples of the works of Rey from the second period works. The second work that Cemal Reşit Rey composed for violoncello and orchestra between 1952 and 1954 is Concertant Pieces. The work consists of four parts that are Largo, Allegretto, Largo Cadenza and Allegretto. Rey dedicated this work to famous violoncello artist Pierre Fournier. The work was presented on 6 May 1954 by French National Orchestra with the soloist Pierre Fournier and with the conduction of Andre Cluytens (Aktüze, 2003: 1869). Famous music critic Marc Rincherle stated the following for this work;

"Let me tell you in advance: This is an excellent piece of music. The composer did not prefer the easiness of using the local patterns exactly as they are and thus he reached originality. For instance, there are local patterns in the second theme of Allegretto, but these are temporary. It is possible to sense a characteristic in melody and harmony that does not exaggerate modernity. Also, he finds a solution for a difficult problem. He brings the violoncello that is known as a weak instrument to the foreground among a full complement symphonic group that uses all the possibilities. Cemal Reşit owes this highly important achievement to his experiences as a maestro." Aktüze, 2003:1869) When examining historically, it is possible to consider this work as one of his last period works. Rey cared more about Sufism and Turkish music in his last period works and composed wide scaled orchestral works. "Katibim" (variations for piano and orchestra), 1953, "Two Pieces", 1959, "Colloqye Instrumental”, 1957, “"Andante et Allegro" (for violin solo and string orchestra), 1969 are examples of Rey’s works from his last period.

\section{Hasan Ferit Alnar (1906- 1978)}

Hasan Ferit Alnar was born on 11 March 1906 in İstanbul. He is the one who was attached to Classical Turkish Music most among Turkish Five. Alnar started to get interested in music because his mother and uncle were interested in music. In Orchestra Magazine where he wrote his own biography, he talked about his experiences with these words; "I wanted to learn how to play the violin. My uncle said that it might interfere with my studies. 
When I was ten, I saw that the names of the notes were written next to the strings of the zither at home. I asked one of my friends to write the names of the notes of anthem "Ordumuz Etti Yemin". I searched for the sounds (I had already known the melody and rhythm by heart), I started to play the anthem I mentioned. I found the notes of a few other pieces, too. Later, zitherist Vitali who visits our house every week for practice listened to me. He started to teach me and four months later he said that I had nothing more to learn (Uçar, 2014:3). Alnar who became one of the known zitherists when he was just 12, composed his first operetta when he was 16 . He started to take harmony lessons from Saadettin Arel whom he met in 1923, and counterpoint and fugue lessons from Edgar Manas. He attended Academy of Music and Performing Art in Vienna after he had won the competition organized by the ministry of education in 1927 . He had studied composition with Joseph Marx and conductorship with Oswald Kabasta, he graduated in 1932 and came back to Turkey. He started to work as a maestro at İstanbul City Theatre and as a history of music at İstanbul State Conservatory. After he had lived for four years in İstanbul, he moved to Ankara and was assigned as an assistant conductor at Presidential Symphony Orchestra. Alnar who started to teach piano and composition at Ankara State Conservatory in 1936, became the general manager at Ankara State Opera and Ballet in 1955. After a while, he quitted this job and moved back to Vienna and had the opportunity to work with many orchestras in Europe. He came back to his homeland in 1964 and continued to work as a teacher at Ankara Conservatory until 1978 (İlyasoğlu, 2007: 33). The composer who could play zither, kemancha, piano and violoncello produced many works related to singing, opera, chamber music and solo instruments. There are two works that are performed most and are regarded as the most brilliant ones among Alnar's work. These are Violoncello Concerto that he composed in 1942 and Zither Concerto written in 1944. Zither Concerto is the first concerto that is written for a Turkish Music instrument, and Violoncello Concerto is the first Turkish Concerto written for a violoncello. Violoncello Concerto was performed by Presidential Sypmhony Orchestra with David Zirkin on 15 February 1943. He explained why he composed this concerto through these words: "Violoncello is an instrument that indicates the melody very well and it is the one whose tone is the closest to the human voice." (Uçar, 2014:16). Violoncello Concerto composes of three parts. The first part was in Moderato and the theme presented by the violoncello first is in Nikiz, the second one is in Hüseyni and Uşşak. The second part which is in Largo non troppo has a mystical and calm expression. Turkish music themes are also used in this part, violoncello and orchestra is in a dialogue. The third part which is in a joyful and bright Allegro con brio beat is a rondo where Turkish themes and contemporary techniques come together. The composer, who grew up in Turkish music culture, used this influence for the works he composed for western music instruments, as well. (Aktüze, 2002:48)

\section{Ulvi Cemal Erkin (1906-1972)}

The artist who was born on 14 March 1906 started his musical education at the age of 8 . The piano lessons which he started with his mother, continued with Mercenier and Adinolfi and he achieved great success in a short amount of time. He graduated from Galatasaray High School in 1925 and after passing the exam held by Ministry of National Education, he went to Paris. He was the first Turkish student who got accepted to Paris Conservatory via an exam. He learned piano from Camille DeCreus and Isidor Phillipp, harmony from Jean Gallon and counterpoint from Noel Gallon. He studied at Ecole Normale de Musique with Nadia Boulanger in 1929, he graduated from this institution in 1930 and returned to Turkey. (İlyasoğlu, 2007: 39) Erkin who was assigned as a piano and harmony teacher at Music Teacher's School) was transferred to Ankara State Conservatory as the head of piano department in 1936. He conducted Ankara Opera Orchestra for a while and worked as a piano teacher at Gazi Training Institute. He continued his work at Ankara State Conservatory until his death in 1972. Erkin who had a wide range of works of art in wrote a lot of works including ballet music, chorus music, symphonies and works especially for solo violin and piano. He did not have a work that he composed for violoncello. "Köçekçe" among his works was thought to be the most performed piece by him. Andante magazine editor Alexandra Ivanoff evaluated Köçekçe in his article in which he mentioned concert critics in İstanbul ; "This vivacious concert started with "Köçekçe Suite" by Ulvi Cemal Erkin. I can say that the composer who completed most of his education in Paris can effectively immingle the melodic and polyphonic pattern of the east with the ability of imitation of this pattern by western music instruments. The equivalent of this in visual arts is "classic orientalist" painting. This quite colorful and systematical work reflects the musical history of Turkey probably in the most perfect way with its astonishing solo passages, profound dance rhythms, remarkable use of finger ringing, modal musical scales of the east and rhythms with 9/8 scale." (http://www.ulvicemalerkin.com). The enthusiasm of Turkish folk dances and post romantic effects come together with thematic music in the works of Ulvi Cemal Erkin. The composer who care much about the rhythmic characteristics employed syncopated rhythm in Turkish music a lot. He is the only composer whose all works have been performed, and nearly all of them have been recorded. (İlyasoğlu, 2007: 40)

\section{Ahmed Adnan Saygun (1907-1991)}

He was born in İzmir in 1907. He started his musical education in a choir with İsmail Zühtü. He continued his 
piano training that he had started at the age of 13 with Rossati and then with Hungarian Tevfik Bey. After he had graduated from school, he stated to learn harmony from Hüseyin Saadettin Bey. He familiarized himself with the musical theory through the books the had read and the Turkish translation he had done. Among the resources he found, he translated Counterpoint by Erns Fredirich Richter, Harmony and Counterpoint by Salomon Jadosshon, "The Life and Works of Wagner", and all the articles in La Grande Encyclopedie into Turkish in 1925-26. He started his first job as a music teacher in primary and high schools between 1924 and 1928. In 1928, he passed the exam held by the Ministry of National Education and was accepted to the Schola Cantorum in Paris. He took harmony and counterpoint lessons from Madame Eugene Borrel, composition lesson from Vincent d'Indy and Paul La Flem, fugue and composition lessons from Monsieur Borrel, organ music lessons from Edouard Souberbielle and Gregor Melodies lessons from Amedee Gastoue (İlyasoğlu, 2007:46). After he had returned to Turkey in 1931, Saygun started to work as a counterpoint teacher at the Music Teacher's School. He was the head of the Presidential Symphony Orchestra for a while. He had settled in Istanbul in 1936 and became a teacher at State Conservatory. In the same year, he traveled around Anatolia with the Hungarian composer Bela Bartok and prepated folk music compilations. He retired from Ankara State Conservatory in 1972 and settled in Istanbul. He continued to teach ethnomusicology and composition at Istanbul Mimar Sinan Fine Arts University until his death in 1991 (Aktüze, 2003:1984). According to Saygun, there was not a single musical culture in Anatolia. Many musical cultures had formed a synthesis by being combined with traditions. The aim of Saygun was to realize a new trend within the framework of the national spirit. The revolutionary spirit in the country was a major factor in the formation of this trend. Saygun's music was very diverse. Sufi music, folk music, tonal music, 12 tones, pentatonism, modal writing were some of the varieties that made up the works of Saygun (Beller, 2018: 10). Ahmed Adnan Saygun produced works in a wide variety of fields. He had 3 works for violoncello. These are;

- Op.12 Sonata for Cello and Piano (1935-1936)

- Op.31 Partita for Solo Cello (1955)

- Op.74 Concerto for Cello and Orchestra (1987), respectively.

Saygun's music can be approached as 3 periods. His early music was heavily influenced by folk music. Op.12 Sonata for Violoncello and Piano (1936) is one of the early works by Saygun. Saygun dedicated this piece to the Russian cellist David Zirkin, who taught at the Ankara State Conservatory. It was first performed in Ankara in 1941. Although it is one of the early works by Saygun the language of composition is at a high level. Since Saygun had been working extensively on pentatonicism at the time he wrote this sonata, pentatonic effects were frequently employed in this work. There are very difficult technical passages for violoncello and piano, and the modal and theme structures are in the foreground in this work. (Beller, 2018: 13). Saba, Hicaz, Bestinigar and Hüseyni are among the themes that were used in this work. His travels to Anatolia which coincided with the period of Saygun's early music, also influenced his music. He combined Anatolian melodies with the principles of Bartok and Kodaly. Thematic music was the priority of this period. Taş Bebek and Özsoy operas are also among the examples of the works by Saygun in his early period. These works were also influenced by the political events of the period. In the second period, the philosophy of mysticism became remarkable in his music. Yunus Emre Oratorio is one of the most important works in this period. As a researcher working on Yunusemre and Sufi philosophy, Annemarie Schimmel said after the premiere that "No one can escape the magic of this work, which skillfully combines modern music and the hymns sung by dervishes in their lodges." This work, which was a milestone in Saygun's life, made the composer not only a national composer, but also enabled him to open up to the world as someone who composed contemporary classical western music (Beller, 2018: 11). Op.31 Partita for Solo Violoncello (1955) is among the examples of works by Saygun in his second period. Partita, which is the most performed work by violoncello artists, is a work that is known worldwide. The famous violoncello player Yo-Yo Ma included the 4th part of Partita into his repertoire. After his performance of the work in 2001 as a part of the "Silk Road Project" and the fourth Allegretto part of the work was included to the album "A Playlist Without Borders" published in 2013. While the reflections of the international success of the work was continueing, it is known that Ban Ki Moon, who took over the duty of United Nations Secretary General from Kofi Annan, listened to the work from Yo-Yo Ma in the ceremony and willed this piece to be played at his funeral one day (Doğangün, 2015: 68). All the elements of Turkish music were included in Partita. Significant indicators of Turkish music such as Sufi philosophy, Anatolian melodies, and syncopated rhythms were immingled in this work masterfully. It is observed that Saygun moved away from the classical discipline in his works from his last period. One can observe a more pessimistic, introverted musical language. Saygun who had presented post- romantic music was completely stripped of his nationalist identity. This style drew attention especially in his chamber music works, symphonies and concertos that he composed in this period. Impressionist tones reminded the music of composers such as Hindemitth, Debussy and Wagner. Köroğlu opera was one of the important works from this period. Saygun dedicated this opera to Mustafa Kemal Atatürk (Beller, 2018: 11). Op. 74 Concerto for Violoncello and Orchestra (1987) was also among the works by Saygun in last period. The work which was in a pessimistic mood also contained impressionist melodies 
throughout the work. The orchestra solo was as effective as the violoncello. The concept of endless melody (the name given to the basic motive that creates the rhythm and unity that is repeated intermittently in a work of art) could be considered for this work. When the whole work is analyzed, it is possible to evaluate it as a motive work.

\section{Necil Kazım Akses (1908-1999)}

He was born in İstanbul on 6 May 1908. He started to take violin lessons at the age of 7 . He attended harmony classes by Cemal Reşit Rey during his education at İstanbul Male High School. He also took violoncello lessons from Mesud Cemil and Sezai Asal in this period. He was accepted to Vienna State Music and Performance Academy in Austria where he went through his own means in 1926. He studied violoncello with Walter Kleinecke and composition with Joseph Marx. He had gained the scholarship awarded by the Ministry of National Education in 1927 and continued his education with this scholarship. While he was continuing his master's degree, he enrolled in Prague State Conservatory. He studied higher composition with Josef Suk and microtonal music with Alois Haba in Prague. He graduated from advanced composition departments of both conservatories successfully, and came back to Turkey in 1934. He started to work as a teacher and an assistant director at Music Teacher's School in Ankara. He was assigned to a duty for the establishment of Ankara State Conservatory and he worked with Paul Hindemith who was invited to Turkey by the Ministry of National Education in 1935. Later, he joined folklore researches in Adana with Bela Batok and Ahmed Adnan Saygun. Akses worked in many fields such as Ankara State Conservatory manager, Fine Arts General Manager, Cultural Attache and General Director of State Opera and Ballet. (İlyasoğlu, 2007: 59-60). Akses was an artist who composed big symphonies. He composed three works for violoncello. These are;

- $\quad$ Poem - for Violoncello and Orchestra (1946)

- $\quad$ İdil - for Violoncello and Orchestra (1980)

- No.4 Sinfonia Romancesca Fantasia for Violoncello and Orchestra (1984)

It is possible to evaluate his music in four periods. His works from the first period were from the years he spent as a student in Europe. The works he composed from 1929 to 1934 were the works where he was in search of creating an atonal style. Prelude and Fugue for piano, Piano Sonata and Mete Opera were among the examples of his work from the first period. Akses composed his opera called "Bayönder" by the request of Atatürk in 1934. The works he composed after 1934 were under the influence of traditional Turkish and folkloric music just like the other composers of that time (İlyasoğlu, 2007: 60). The music of Necil Kazım Akses stated a new period along with 1940s. "Akses Style" started to appear especially through the symphonic works he composed in this period. The characteristic of this style was to be based on Turkish themes melodically, and they presented - with the words of the composer- a-modality in terms of harmony. His long lasting works such as The Citadel of Ankara, Ballade, Symphony No.1, Violin Concerto, Scherzo on Itri's Neva Kar and Ten Piano Pieces started to appear in this period. "Poem" which was his first composition for violoncello was written in 1946. Post-romantic style was one of the most apparent characteristics of the work. Post-romanticism represents extreme wideness of content and design, a mixture of various musical forms (for instance opera and symphony) and increasing counterpoint sophistication (that is to say each two of long or wide scales or simultaneous but individual musical scales or events). Post-romanticism also embraces vivid religious or mystical enthusiasm, sense of longing and brutal and grotesque emotions (https://delphipages.live/tr/eglence-ve-pop-kultur/muzik-klasik/postromanticmusic). All the properties mentioned in this explanation is also valid for Poem. Akses used post-romanticism in the works he composed in that period, as well. For instance, Ballade for orchestra which he composed in 1947 represented the pursuit of earthly pleasures of a man who was had mystic idea through dance. Ballade means the song that accompanies dance in Italian and the work starts with the reflection of the still body of a praying person through heavy and dark tones. This is one of the effects of post-romanticism.

The works that the composer wrote after 1976 can be considered as the last period. The composer composed pieces such as choir, soloists, and big orchestral works in that maturity period. He benefited from many aspects of 20th century music, such as the randomness of intense orchestral music (İlyasoğlu, 2007: 61). Other works he wrote for violoncello were "Idil" and "Sinfonia Romenesca Fantasia" for Cello and Orchestra. Both were the examples of the works from the last period of the composer. Akses who was an innovative composer used quite different tones in his works from this period, and was on the side of integrity. "İdil", which was written in 1980, was first played in 1981 by cellist Doğan Cangal, accompanied by the Presidential Symphony Orchestra with the maestro Gürer Aykal. Music in the pastoral character gave the violoncello the opportunity to present a melody of nature. The colorfulness in the orchestra accompanied the violoncello. İdil was later arranged for viola and orchestra, and its first performance was by the Istanbul State Symphony Orchestra with the soloist Koral Çalgan and with the conduction of maestro Cem Mansur (Aktüze, 202: 26). His last work for violoncello, on which he worked for many years, was "Sinfonia Romenesca Fantasia". After listening to the Benjamin Britten Op.68 Cello symphony brought to him by Doğan Cangal, Akses started to work on this piece. The work first became a symphony with a solo violoncello, and when it was completed in 1983, it 
was named the 4th Symphony. The first performance of the piece was performed in 1987 with the Presidential Symphony Orchestra with the conduction of Rengim Gökmen, and Doğan Cangal as the soloist. This piece was also among the last period works of Akses. The mystical and flat music at the beginning of the work, then gave a way to an intense orchestration. The contemporary structure of Akses demonstrated itself in this work.

\section{Conclusion}

Turkish Five had a big part in the development and spread of contemporary Turkish music. In this study, considering the historical periods, violoncello works by Turkish Five were discussed by comparing and contrasting the similarities and differences among the other works written by these composers at that time. When the artistic lives of the composers were analyzed by separating into periods, it was concluded that each of them developed a musical character in line with their own musical period, which elements they used in each of the works composed and they included elements from different periods in terms of notation. Each composer was influenced by the musical culture of the country where they were to complete conservatory education they won in the first years of their musical period. The works from their first periods were generally works containing classical western music elements. When the violoncello works were examined, it was observed that the violoncello works that were among the works from the first periods of the composers were also under the influence of western music. Composers, who returned to their country after completing their education abroad and worked at various positions, synthesized contemporary western music techniques with Turkish music melodies in the second period of their musical lives. Elements such as Turkish themes, syncopated rhythms and pentatonic structure used in their works from the second period became the defining characteristics of their works. Turkish themes and pentatonic structure were also used in the works composed for violoncello. When the composers reached the last period of their musical life, mysticism and mystic elements were frequently included in their works. The music of the last period was mostly great symphonies, concertos or opera works. Except for Ulvi Cemal Erkin, Turkish Five composers added many works to the violoncello repertoire. These works, which were brought to the repertoire, have been performed many times in our country and around the world. These works, which are also included in the curriculum of conservatories, are of great importance for young cellists to get to know Turkish works and introduce Turkish music to future generations.

\section{References}

İlyasoğlu, E. (2007), “71 Türk Bestecisi” İstanbul: Pan Yayıncılık.

Aktüze, İ. (2004), “Müziği Okumak Part 1" İstanbul: Pan Yayıncılık

Aktüze, İ. (2002), "Müziği Okumak Part 2" İstanbul: Pan Yayıncılık

Aktüze, İ. (2003), "Müziği Okumak Part 4" İstanbul: Pan Yayıncılık

Uçar Demir, B. (2014), "Hasan Ferid Alnar Viyolonsel Konçertosu Birinci Bölüm (Moderato) İncelemesi”, İstanbul, Haliç Üniversitesi Sosyal Bilimler Enstitüsü Türk Musikisi Anasanat Dalı Türk Musikisi Programı

Beller, A. (2018), “Ahmed Adnan Saygun'un Viyolonsel Eserlerinin Biçimsel ve Teknik Incelenmesi”, Eskişehir, Anadolu Üniversitesi Güzel Sanatlar Enstitüsü

Doğangün, D. (2015), “Ahmed Adnan Saygun'un Op.31 'Viyolonsel İçin Solo Partita'sl Ve Eserin 1955 Türkiye’si Sanat Hayatındaki Yeri “, İnönü Üniversitesi Kültür ve Sanat Dergisi, Vol.1, No.1 (61-69)

http://www.turkishmusicportal.org/tr/turk-muzigi-turleri/cagdas-turk-muzigi-cumhuriyetin-ilani-ve-turkiyedemuzik-inkilabi

https://ataturkansiklopedisi.gov.tr/bilgi/turk-besleri

http://www.ulvicemalerkin.com

https://delphipages.live/tr/eglence-ve-pop-kultur/muzik-klasik/postromantic-music 